\title{
P015: Prevention of re-use of single-use suction catheter decreased the vap incidence density in a resource-limited adult ICU in Egypt
}

\author{
M Enany ${ }^{*}$, M Sherif, AA El Kholy, GL Saeed, E Sobhy \\ From 2nd International Conference on Prevention and Infection Control (ICPIC 2013) \\ Geneva, Switzerland. 25-28 June 2013
}

\section{Introduction}

Ventilator-associated pneumonia (VAP) had a major impact on patient morbidity and mortality in our ICU, an adult ICU in a tertiary hospital, in spite of application of ventilator- associated pneumonia prevention (VAP) bundle. Between March 2009 and May 2010 the incidence rate was 17/1,000 device-days.

\section{Objectives}

This study aimed to identify and correct unsafe procedures related to care of the ventilated patient.

\section{Methods}

Due to limited resources, the suction catheter was found to be reused for the same patient during a working shift (6 hours). This practice was prohibited and the hospital management was convinced to provide adequate regular supplies of single- use suction catheters. A new policy for suctioning was written and implemented.

\section{Results}

From June 2010 till December 2012, a new sterile single- use catheter was used for each suction procedure then discarded immediately after single- use. The incidence rate was decreased to $5.6 / 1,000$ device-days by the end of 2012 (67\% decrease).

\section{Conclusion}

Re-use of single- use supplies contributes to increasing the rate of healthcare- associated infections in lowresource settings. The infection preventionist should make a business case of infection control and analyze the cost- effectiveness of interventions.

Cairo University, Cairo, Egypt

\section{Disclosure of interest}

None declared.

Published: 20 June 2013

doi:10.1186/2047-2994-2-S1-P15

Cite this article as: Enany et al:: P015: Prevention of re-use of single-use suction catheter decreased the vap incidence density in a resourcelimited adult ICU in Egypt. Antimicrobial Resistance and Infection Control 2013 2(Suppl 1):P15.
Submit your next manuscript to BioMed Central and take full advantage of:

- Convenient online submission

- Thorough peer review

- No space constraints or color figure charges

- Immediate publication on acceptance

- Inclusion in PubMed, CAS, Scopus and Google Scholar

- Research which is freely available for redistribution

\section{( Biomed Central}

\section{Cairo University, Cairo, Egypt}

\section{() Biomed Central}

C 2013 Enany et al; licensee BioMed Central Ltd. This is an Open Access article distributed under the terms of the Creative Commons Attribution License (http://creativecommons.org/licenses/by/2.0), which permits unrestricted use, distribution, and reproduction in any medium, provided the original work is properly cited. 